\section{Aminoglycoside Antibiotics Inhibit Shoot Regeneration from Siberian Elm Leaf Explants}

\author{
James A. Kapaun ${ }^{1}$ and Zong-Ming Cheng ${ }^{2}$ \\ Department of Plant Sciences, North Dakota State University, Fargo, \\ ND 58105-5051
}

Additional index words. genetic transformation, selective markers, Ulmus pumila, kanamycin, neomycin, geneticin, paromomycin

\begin{abstract}
Four aminoglycoside antibiotics were evaluated for their effects on shoot regeneration from leaf explants of Siberian elm (Ulmus pumila L.) seedlings and their potential use as selective agents in genetic transformation with the neomycin phosphotransferase II gene as the selective marker gene. Kanamycin at $100 \mathrm{mg} \cdot \mathrm{L}^{-1}$ or higher concentration reduced shoot regeneration, with complete inhibition at $225 \mathrm{mg} \cdot \mathrm{L}^{-1}$, and was considered a suitable selective agent. Neomycin completely inhibited shoot regeneration at $450 \mathrm{mg} \cdot \mathrm{L}^{-1}$, but all explants remained green; therefore, it may also be used as a selective agent. Geneticin significantly inhibited shoot formation at $1 \mathrm{mg} \cdot \mathrm{L}^{-1}$ and completely killed the explants at $4 \mathrm{mg} \cdot \mathrm{L}^{-1}$ after 1 week. Geneticin was too toxic for direct selection, but may be useful in a delayed selection scheme or for confirmation of transformation. Paromomycin was least effective in inhibiting shoot formation; $13 \%$ of explants still regenerated shoots on the medium with the highest concentration tested $\left(400 \mathrm{mg} \cdot \mathrm{L}^{-1}\right)$. Both neomycin and paromomycin precipitated in media containing Phytagel as a gelling agent if antibiotic stock solutions were added to the medium without adjusting their $\mathrm{pH}$. Precipitation was prevented by adjusting the $\mathrm{pH}$ of the stock solutions from 6.2 (neomycin) or 6.9 (paromomycin) to above 9, or by using agar as a gelling agent. The precipitation was not affected by the concentrations of salts in the media.
\end{abstract}

Siberian elm was one of the popular tree species for windbreak planting in the northern Great Plains of the United States because of its high resistance to Dutch elm disease [Ophiostoma ulmi (Buism.) Nannf.]. However, it is no longer recommended because of its high sensitivity to 2,4-dichlorophenoxyacetic acid (2,4-D), a herbicide commonly used to control broad-leaved weeds in adjacent fields (Quam et al., 1991). We are interested in improving Siberian elm by genetic engineering with a 2,4-D degradation gene (Streber and Willmitzer, 1989). We have developed reliable micropropagation (Cheng and Shi, 1995) and regeneration (Kapaun and Cheng, 1997) systems. One of the requirements for transforming Siberian elm is a suitable selective agent for identifying tissues transformed with Agrobacterium tumefaciens

Received for publication 24 Aug. 1998. Accepted for publication 12 Oct. 1998. This research was supported in part by the U.S. Dept. of Agriculture Forest Service grant 28-C2-802 and the McIntireStennis Project ND6207. We thank Wayne Sargent for helpful suggestions and assistance. We also thank Drs. R. Novy and L. Dahleen for reviewing the manuscript. The cost of publishing this paper was defrayed in part by the payment of page charges. Under postal regulations, this paper therefore must be hereby marked advertisement solely to indicate this fact.

${ }^{1}$ Former Graduate Research Assistant.

${ }^{2}$ Associate Professor; to whom reprint requests should be addressed. Phone: (701)-231-7405; fax:

(701)-231-8474; e-mail: zcheng@ plains.nodak.edu or bombarded with microprojectiles. The selective agent must allow transformed cells to grow into calli, then regenerate into whole plants, while nontransformed cells will be inhibited or killed.

One of the most commonly used selective marker genes is the neomycin phosphotransferase II (nptII), which encodes a phosphotransferase capable of phosphorylating aminoglycoside antibiotics [kanamycin, geneticin (G418), neomycin, and paromomycin]. These antibiotics inhibit growth of plant cells by binding to the $30 \mathrm{~S}$ ribosomal subunit, thereby inhibiting initiation of plastid translation (Wilmink and Dons, 1993). Plant cells transformed with the nptII gene can detoxify the antibiotic in the selection medium. The biological activities of the different aminoglycoside antibiotics can impact selection and transformation efficiency (Norelli and Aldwinckle, 1993). Too high a concentration of antibiotic may kill the nontransformed cells, thereby inhibiting regeneration from transformed cells (Escandon and Hahne, 1991). Alternatively, if insufficient antibiotic is provided, the nontransformed cells may overgrow and also inhibit regeneration of transformed cells. The objective of this research was to determine the effects of four aminoglycoside antibiotics on shoot regeneration from leaf tissue of Siberian elm seedlings and to evaluate their potential for selecting transformed cells. Early in the study, neomycin and paromomycin were found to precipitate in medium; therefore, methods of maintaining their solubility were also evaluated.
The leaf explants from Siberian elm seedlings were collected, sterilized, and induced to produce shoots according to procedures described by Kapaun and Cheng (1997). Young leaves from greenhouse-grown plants were excised, sterilized, and placed on a medium containing MS salts and vitamins (Murashige and Skoog, 1962), 10 $\mu \mathrm{m}$ of benzylaminopurine (BA), and 3.0\% (w/v) sucrose, and solidified with $0.3 \%$ Phytagel (Sigma Co., St. Louis). Each medium was supplemented with one of four aminoglycoside antibiotics, which were filter-sterilized and added to the cooled medium $\left(\approx 50{ }^{\circ} \mathrm{C}\right)$ after autoclaving. The stock concentrations were kanamycin at $50 \mathrm{mg} \cdot \mathrm{mL}^{-1}$, geneticin disulfate salt (G418) at $0.5 \mathrm{mg} \cdot \mathrm{mL}^{-1}$, neomycin at $20 \mathrm{mg} \cdot \mathrm{mL}^{-1}$, and paromomycin at $20 \mathrm{mg} \cdot \mathrm{mL}^{-1}$. Neomycin and paromomycin stocks were adjusted to $\mathrm{pH} 9.0$ unless indicated otherwise. The final ranges of concentrations $\left(\mathrm{mg} \cdot \mathrm{L}^{-1}\right)$ of antibiotics were: kanamycin monosulfate (100-250), geneticin disulfate (1-10), neomycin sulfate (200-500), and paromomycin sulfate (100-400). A completely randomized design was used for these experiments. Each experiment was conducted twice. Three replications $(15 \times 100-\mathrm{mm}$ petri plates $)$, each with eight leaf explants, were used for each treatment, including the control, in each experiment. The percentages of explants forming callus and regenerating at least one shoot were determined 4 weeks after initial placement onto each medium. Data were arcsin transformed and then subjected to analysis of variance, using the general linear models procedure with the protected Fisher's least significant difference mean separation technique at $P \leq 0.05$ (SAS Institute, 1990). Data from the two separate experiments were combined because the difference between the experiments was nonsignificant.

In early attempts to add neomycin and paromomycin stocks into cooled medium $(\approx 50$ $\left.{ }^{\circ} \mathrm{C}\right)$, milky white precipitate formed and the antibiotics did not disperse evenly in the medium. Gelling agents, $\mathrm{pH}$, and basal salt concentrations were then examined to correct the precipitation problem. When the antibiotic powders were dissolved directly into distilled water, the $\mathrm{pH}$ of the stock solution was 6.9 for neomycin and 6.2 for paromomycin. The stock solution of neomycin was adjusted with $\mathrm{NaOH}$ or $\mathrm{HCl}$ to $\mathrm{pH} 5.0,6.0,6.9$ (nonadjusted), 8.0, 9.0 , or 10.0 before adding to the medium. The paromomycin stock solutions were similarly adjusted to pH 5.0, 6.2 (nonadjusted), 7.0, 8.0, 9.0, or 10.0. The effect of each gelling agent on precipitation was examined with three concentrations of agar $\left(0.0,3.5\right.$, and $\left.7.0 \mathrm{~g} \cdot \mathrm{L}^{-1}\right)$ (A1296, Sigma) and Phytagel (0, 1.5, and 3.0 $\left.\mathrm{g} \cdot \mathrm{L}^{-1}\right)$ (P 8169, Sigma). The concentration of mineral salts in the medium (either one-half or full strength) was also tested in a factorial combination with gelling agents. In all experiments, $0.1 \mathrm{~mL}$ of stock solution was added to $2.5 \mathrm{~mL}$ of autoclaved, cooled medium $\left(50^{\circ} \mathrm{C}\right)$ in $15 \mathrm{~mL}$ test tubes. Three test tubes were used for each treatment and precipitation was determined visually. 


\section{Results}

Callus formation was not affected by kanamycin at 100 to $125 \mathrm{mg} \cdot \mathrm{L}^{-1}$, but was partially or completely inhibited at 200 to $225 \mathrm{mg} \cdot \mathrm{L}^{-1}$ (data not shown). Shoot regeneration was reduced by kanamycin at concentrations of 100 $\mathrm{mg} \cdot \mathrm{L}^{-1}$ or higher, with complete inhibition at $225 \mathrm{mg} \cdot \mathrm{L}^{-1}$ (Fig. 1A). Explants on MS medium containing $225 \mathrm{mg} \cdot \mathrm{L}^{-1}$ kanamycin were slightly bleached. Geneticin at low concentrations $\left(4 \mathrm{mg} \cdot \mathrm{L}^{-1}\right)$ completely inhibited both callus (data not shown) and shoot (Fig. 1B) formation. Explants on media containing 2 to $10 \mathrm{mg} \cdot \mathrm{L}^{-1}$ of geneticin turned brown after 1 week of culture and were dead after 2 weeks. Shoot regeneration seemed to be stimulated by neomycin at 200,250 , and $300 \mathrm{mg} \cdot \mathrm{L}^{-1}$, but was completely inhibited at $450 \mathrm{mg} \cdot \mathrm{L}^{-1}$ (Fig. $1 \mathrm{C})$, with all explants remaining green. Rates of shoot regeneration decreased as concentrations of paromomycin increased to $400 \mathrm{mg} \cdot \mathrm{L}^{-1}$, even though shoot formation still occurred (Fig. 1D). Explants were necrotic on media containing all concentrations of paromomycin.

Neomycin and paromomycin precipitated in the medium when the stock solution $\mathrm{pH}$ was below 9, but not when the $\mathrm{pH}$ was adjusted to $\mathrm{pH} 9$ or 10 (data not shown). Precipitation (milky white globules) occurred in media only when Phytagel was used as the gelling agent and the $\mathrm{pH}$ of stock solutions was not adjusted. Changes of salts or Phytogel in the medium to half-strength did not change the results (data not shown). When agar was used as the gelling agent, precipitation was not observed regardless of stock solution $\mathrm{pH}$ (data not shown).

\section{Discussion}

Successful development of an efficient genetic transformation system for Siberian elm requires an effective selection protocol such that the nontransformed cells will be inhibited and only transformed cells will form shoots. Siberian elm leaf tissue responded very differently to the four aminoglycoside antibiotics. Kanamycin will be useful in the selection of transformed Siberian elm because both callus and shoot formation were inhibited at moderate concentrations. Kanamycin is used successfully to select transformants in many plants, including several tree species, such as sweetgum (Liquidambar styraciflua L.) (Sullivan and Lagrimini, 1993), quaking aspen (Populus tremuloides Michx.) (Tsai et al., 1994), and almond [Prunus dulcis (Mill.) D.A. Webb] (Archilletti et al., 1995).

Geneticin is used for selection in transformation of rice (Oryza sativa L.) (Dekeyser et al., 1989) and Arabidopsis thaliana (L.) Heynh. (Schmidt and Willmitzer, 1988). However, geneticin was much more toxic to Siberian elm leaf explants than were the other three aminoglycoside antibiotics. Because of its high toxicity, geneticin is also unsuitable as a selective agent in sugar beet (Beta vulgaris L.) (Catlin, 1990) and apple (Malus $\times$ domestica Borkh.) (Norelli and Aldwinckle, 1993). Geneticin quickly killed nontransformed cells,
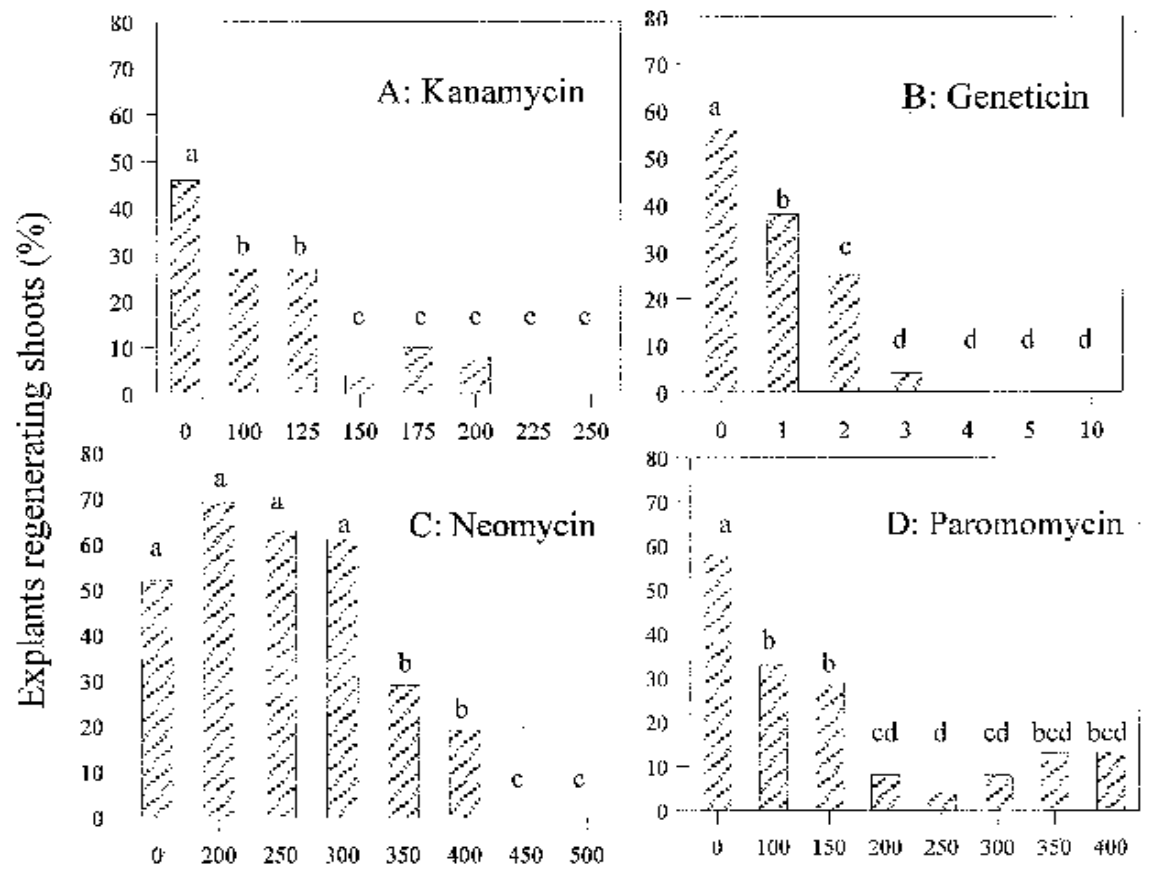

\section{Concentration (mg $\mathrm{L}^{-1}$ )}

Fig. 1. The effect of aminoglycoside antibiotics on shoot regeneration from leaf explants from greenhousegrown Siberian elm after 4 weeks of culture on Murashige and Skoog (MS) medium $+10 \mu \mathrm{M} \mathrm{BA}+3.0 \%$ $(\mathrm{w} / \mathrm{v})$ sucrose $+0.3 \%(\mathrm{w} / \mathrm{v})$ Phytagel. Values are averages for two experiments, each with three petri plates per treatment and eight explants per plate. Mean separation within antibiotics by Fisher's LSD at $P \leq 0.05$.

which may prevent the transformed cells from regenerating into shoots. Geneticin should not be used for immediate selection after cocultivation of Siberian elm leaf explants with Agrobacterium or after bombardment with microprojectiles, but may be used in a delayed selection scheme in which a less toxic aminoglycoside antibiotic is used in the initial selection. Once shoots form, they may be transferred to a medium containing geneticin to eliminate nontransformed shoots.

Neomycin had an effect similar to that of kanamycin as a selective agent. Because of its relatively low toxicity, neomycin is considered a better antibiotic than kanamycin for selecting transgenic sugar beet (Catlin, 1990) and apple (Norelli and Aldwinckle, 1993). Neomycin at low concentrations stimulates shoot regeneration and increases shoot elongation, which may also benefit transformation (Norelli and Aldwinckle, 1993).

Paromomycin has been used successfully as a selective agent in transformation of oat (Avena sativa $\mathrm{L}$.) at 50 to $150 \mathrm{mg} \cdot \mathrm{L}^{-1}$ (Torbert et al., 1995), of apple at 25 to $63 \mathrm{mg} \cdot \mathrm{L}^{-1}$ (Norelli and Aldwinckle, 1993), and of Citrus at 20 to $40 \mathrm{mg} \cdot \mathrm{L}^{-1}$ (Vardi et al., 1990). $\mathrm{Pa}$ romomycin was inadequate for selection in Siberian elm because complete inhibition of callus and shoot formation did not occur even though tissues showed necrosis at the concentrations tested. Kanamycin, neomycin, and possibly geneticin, at concentrations found to inhibit callus and shoot formation, will be used in future transformation experiments to select for transformed cells and shoots.

Neomycin and paromomycin seem to be precipitated by the interaction of low $\mathrm{pH}$ stock solutions and the Phytagel used to solidify the medium, but not by the concentration of salts in the medium. The exact reason for this interaction of $\mathrm{pH}$ with Phytagel is not known. All aminoglycosides tend to precipitate to some degree in media containing Phytagel (J. Norelli, personal communication). To prevent precipitation, agar could be used in place of Phytagel as the solidifying agent for many species, but this cannot be done with Siberian elm (Cheng and Shi, 1995) and some other species, such as Eucalyptus grandis Anth. (MacRae and van Staden, 1990), because agar inhibits shoot development in these species. In these situations, precipitation can be easily corrected by adjusting the $\mathrm{pH}$ of antibiotic stock solutions to 9 or 10 .

In summary, kanamycin was found to be the most suitable aminoglycoside antibiotic for selection of Siberian elm when the nptII gene is to be used as the selective marker gene. Neomycin may also be used. Geneticin was very toxic to Siberian elm tissues, but may be useful in a delayed selection scheme. Paromomycin is not suitable for selection because of its inability to inhibit callus formation and shoot regeneration. The precipitation of neomycin and paromomycin can be prevented by adjusting the $\mathrm{pH}$ of stock solutions to 9 or higher before adding to medium solidified with Phytagel, or by using agar as the gelling agent. 


\section{Literature Cited}

Archilletti, T., P. Lauri, and C. Damiano. 1995. Agrobacterium-mediated transformation of almond leaf pieces. Plant Cell Rpt. 14:267272.

Catlin, D.W. 1990. The effect of antibiotics on the inhibition of callus induction and plant regeneration from cotyledons of sugarbeet (Beta vulgaris L.) Plant Cell Rpt. 9:285-288.

Cheng, Z.-M. and N.-Q. Shi. 1995. Micropropagation of mature Siberian elm (Ulmus pumila L.) in two steps. Plant Cell Tiss. Organ. Cult. 41:197-199.

Dekeyser, R., B. Clases, M. Marichal, M. van Montagu, and A. Caplan. 1989. Evaluation of selectable markers for rice transformation. Plant Physiol. 90:217-223.

Escandon, A. and G. Hahne. 1991. Genotypes and composition of culture medium are factors important in the selection for transformed sunflower (Helianthus annuus) callus. Physiol. Plant. 81:367-376

Kapaun, J.A. and Z.-M. Cheng. 1997. Plant regen- eration from leaf tissues of Siberian elm. HortScience 32:301-303.

MacRae, S. and J. van Staden. 1990. In vitro culture of Eucalyptus grandis: Effect of gelling agents on propagation. J. Plant Physiol. 137:249-251.

Murashige, T. and F. Skoog. 1962. A revised medium for rapid growth and bioassays with tobacco tissue cultures. Physiol. Plant. 15:473-497.

Norelli, J.L. and H.S. Aldwinckle. 1993. The role of aminoglycoside antibiotics in the regeneration and selection of neomycin phosphotransferasetransgenic apple tissue. J. Amer. Soc. Hort. Sci. 118:311-316.

Quam, V.C., D.E. Herman, and E. Behrens. 1991. Trees and shrubs of North Dakota. North Dakota State Univ. Ext. Serv. Bul. EB-38, Fargo.

SAS Institute. 1990. SAS user's guide: Statistics. SAS Inst., Cary, N.C.

Schmidt, R. and L. Willmitzer. 1988. High efficiency Agrobacterium tumefaciens mediated leaf disc transformation of Arapidopsis thaliana leaf and cotyledons explants. Plant Cell Rpt. 7:583-586.

Streber, W.R. and L. Willmitzer. 1989. Transgenic tobacco plants expressing a bacterial detoxifying enzyme are resistant to 2,4-D. Bio/Technol. 7:811-816

Sullivan, J. and L.M.Lagrimini. 1993. Transformation of Liquidambar styraciflua using Agrobacterium tumefaciens. Plant Cell Rpt. 12:303-306.

Torbert K.A., H.W. Rines, and D.A. Sommers. 1995. Use of paromomycin as a selective agent for oat transformation. Plant Cell Rpt. 14:635640

Tsai, C.-J., G.K. Podila, and V.L. Chiang. 1994. Agrobacterium-mediated transformation of quaking aspen (Populus tremuloides) and regeneration of transgenic plants. Plant Cell Rpt. 14:94-97.

Wilmink, A. and J.J.M. Dons. 1993. Selective agents and marker genes for use in transformation of monocotyledonous plants. Plant Mol. Biol. Rptr. 11:165-185.

Vardi, A., S. Bleichman, and D. Aviv. 1990. Genetic transformation of Citrus protoplasts and regeneration of transgenic plants. Plant Sci. 69:199206 